\title{
Measurement of the Human Capital Applied to the Business Eco-Innovation
}

\author{
Raquel Ortega-Lapiedra ${ }^{1}$, Miguel Marco-Fondevila ${ }^{2, *}$, Sabina Scarpellini ${ }^{2}$ (I) \\ and Fernando Llena-Macarulla ${ }^{3}$ (I) \\ 1 Department of Management, University of Zaragoza, 1250009 Zaragoza, Spain; rortega@unizar.es \\ 2 Department of Accounting and Finance-CIRCE Institute, University of Zaragoza, 1250009 Zaragoza, Spain; \\ sabina@unizar.es \\ 3 Department of Accounting and Finance, University of Zaragoza, 1250009 Zaragoza, Spain; fllena@unizar.es \\ * Correspondence: mmarcof@unizar.es; Tel.: +34-976-762090
}

Received: 24 April 2019; Accepted: 10 June 2019; Published: 13 June 2019

check for updates

\begin{abstract}
Despite the growing number of studies on eco-innovation, the specific human capital applied to the eco-innovative processes by firms has not been thoroughly analyzed to date. Due to this gap, this study carries out an empirical research about the definition and measurement of the human capital applied to business eco-innovation in terms of knowledge. For this purpose, we define a human capital specific index (HCSI) to analyze the influence of firms' human capital in their eco-innovative activities. The results have been obtained through the analysis of a sample of eco-innovative Spanish firms and they show some relevant implications for practitioners regarding the decision-making process in promoting eco-innovation and for the management control of eco-innovative processes. One of the study contributions for academics is to increase the knowledge about the measurement and the impact of the specific human capital applied to eco-innovation by firms in the theoretical framework of the resource-based view theory (RBV).
\end{abstract}

Keywords: human capital; environmental accounting; eco-innovation; knowledge management; management control

\section{Introduction}

Over the last decade, eco-innovation has been subject to various studies due to the growing number of eco-innovative products and the introduction of eco-innovation in businesses. In summary, eco-innovation is technological innovation based on, or pursuing eco-efficiency [1]. Eco-innovation is performed by businesses with the aim of increasing their competitiveness [2] through innovations to produce new ecological products or to introduce eco-innovative processes based on more sustainable resources and the reduction of waste, and it may lead to varied levels of environmental improvements [3].

In most eco-innovative processes, companies need to organize their resources and capabilities to combine innovation with environmental proactivity and optimize their environmental and financial performance [4]. In fact, there is agreement in the literature regarding the consideration that resources and capabilities of a company are relevant for investments in eco-innovation to reach successful results [5]. Nonetheless, despite the growing number of studies on eco-innovation, the measurement of the specific human capital applied to the eco-innovative processes by firms has not been thoroughly analyzed to date.

The emergence in the 1990s of the resource-based view theory (RBV) and the knowledge-view theory suggested that the success of companies was no longer attributable solely to the access to material resources but rather to intangible assets, and it was that access which could provide a competitive edge in the long term. The growing importance given to human capital has underlined the limits of 
financial measurement systems, which cannot fully evaluate intangible resources and are inadequate to deal with the difficulties inherent to managing the development of new emerging assets.

A very useful feature of the RBV is that it helps explain why some companies work better than others by analyzing resources and internal capabilities as sources of sustainable competitive advantage [6]. With this theory, it is explained how a company uses the available resources through its capabilities in the most efficient way possible, such as in the generation of new knowledge, which cannot be easily imitated [6,7]. Thus, the interrelations that specialized human resources of companies have in eco-innovative processes are considered as competitive competencies that cannot be imitated.

However, the in-depth study of resources and capabilities which are valuable, rare, inimitable, and non-substitutable and that allow the generation of value and competitive advantage [8,9], is still a matter of debate regarding eco-innovation, which can be seen as more expensive than conventional innovation since it involves several areas of the companies in its process [10]. In this sense we can highlight the analysis of the resource human capital as part of intellectual capital involved [11] within the environmental field in the framework of the RBV, which may imply links between eco-innovation and competitiveness based on knowledge [12], because it is a line of research that has not been widely investigated.

If we get into the analysis of the necessary competences to manage the technological intellectual capital [13-15], we can observe different positions in literature $[16,17]$ about the relevance that such competencies may have to improve the environmental performance of companies. Although it can be considered important for conventional innovation, it could not be so for eco-innovation, for instance, in sectors of low technological intensity [18], due to the greater complexity and degree of novelty that eco-innovations entails. The more frequent studies focused on the capabilities of firms in terms of eco-innovation analyze two main aspects. First, the involvement of managerial structures in the process $[19,20]$. Second, the key role played by the responsible leadership in eco-innovation development, as well as their experience or their environmental proactivity [21-25].

The results obtained by the aforementioned authors, although very useful to understand parts of the systemic process of eco-innovation, provide fragmented evidence that may not reach the degree of amplitude necessary to unravel each of the multiple resources and capabilities of the whole, that entails the uniqueness of each eco-innovative company. In fact, although common sense suggests knowledge management and intellectual capital are key to developing any eco-innovation, very little empirical evidence has addressed this relationship due to the complexity of their joint measurement. Thus, we wonder if it is empirically evident that human capital is responsible for creating a sustainable competitive advantage in the eco-innovative activities of business.

With this approach, the paper makes three important contributions. First, defining the variables to measure the human capital applied to eco-innovation by firms in the framework of the RBV, so as to enhance the knowledge about human resources management applied to sustainability eco-innovative processes. Second, defining and measuring the role of the specialized human capital involved in the eco-innovation activities as a relevant factor, which should be specifically managed for the development of eco-innovation in business. Third, analyzing the relationship between human capital and the eco-innovation in firms' processes.

This paper is structured as follows: the following section introduces the theoretical foundations of eco-innovation and human capital in the context of the RBV. Section 3 describes the research methods, sample data, the empirical specifications, and findings. Finally, Section 4 presents the main discussion and conclusions of the research.

\section{Conceptual Framework}

\subsection{Eco-Innovation and $R B V$}

Interest in human capital as a strategic resource arose as part of the development of the RBV in strategic management. As strategy researchers started to identify firm resources that meet the basic 
criteria of the RBV (valuable, rare and not imitable), human capital was highlighted as a resource that could help firms achieve a competitive advantage, and ultimately superior firm-level performance $[8,26]$. The basic idea was that human capital has the potential to be a source of competitive advantage due to three characteristics. (1) A firm's stock of human capital can be a key determinant of the quality of outputs and efficiency of operations (i.e., human capital resources are valuable). (2) Human capital resources are heterogeneously distributed among firms (i.e., human capital resources can be rare). Factors such as specificity, social complexity, and causal ambiguity can hinder the flow and replication of human capital resources (i.e., human capital resources can be difficult to imitate) $[27,28]$. As initial studies showed positive links between the firm's stock of human capital resources and its financial performance [29-32], scholars in the field of strategic management increasingly started to focus their research efforts on human capital as a unique strategic resource.

In the literature, we can find different theoretical perspectives that address the study of companies capabilities for eco-innovation, especially the technological ones [33,34], which are applied to reduce the required resources for production, recycle, prevent pollution, or eco-product design [35-37]. However, we focus our research in the context of the RBV even though the knowledge-based view of the firm might be of interest in order to study the assets related to knowledge that are perceived as key drivers for a sustainable competitive advantage, and often known as intellectual capital or intangible/invisible assets [38]. The RBV is considered in this study because the human capital is one of the resources pointed out for eco-innovation [2].

Starting from the previous literature within the RBV framework, the measurement of specific resources intended for eco-innovation is presented by the staff and directors of the environmental, research and development ( $\&$ \& $)$, and innovation departments and/or by the energy management or resources department [21,39]. The intensity of human resources available here is specifically limited to staff directly or indirectly devoted to eco-innovation. In addition, RBV has also been used as theoretical framework to analyze the resources and capabilities that are applied to eco-innovation by firms for management control and environmental accounting studies [2,40,41].

In some studies, human resources and intellectual capital for eco-innovation have been analyzed for the partial replacement of raw material inputs with human capital [42-45] and their motivation with regard to the environment [46-49]. More specifically, companies increase the added value of products by reducing the intensity of necessary raw materials for their manufacture. In this internal context, Paraschiv, Nemoianu, et al. [44] point out that the availability of specialized human resources to lead activities and who are familiar with the use of environmental management systems [50], represent an especially valuable resource for eco-innovation processes. They include the motivation of both the employees involved in the processes and the managerial attitude regarding the environment [46-48].

The literature proposes and conceptualizes several approaches of intellectual capital (IC), which reflects the wide scope of this concept. But the most remarkable definition in the literature is the one given by Edvinsson and Malone [51], that divides the concept of IC into three categories: human capital, structural (organizational) capital, and relational (customer) capital. Additionally, there is a different model that tries to validate the value of intangible assets, some of them from the accountability side, highlighting the use of financial statement data and monetary models. It is interesting to note that industry has its own definition about IC, in fact, the first commercial one was set up by Skandia AFS [51]. The company internally defined the term as "the possession of knowledge, applied experience, organizational technology, customer relationships, and professional skills that provides Skandia AFS with a competitive edge in the market", serving as a base for the company's internal metrics development. Although in this paper we use the most explicit definition introduced by Edvinsson and Malone [51] as explained above, the latter is especially useful to the aim of this research in order to define and measure the human capital in several eco-innovative companies in view of the IC as a resource that is needed to implement eco-innovation.

Human capital is the profit lever of knowledge economy, rooted in a certain way in the talent of employees [52]. In the literature, it consists of components such as knowledge, expertise, skills, 
experience, competence, creativity, teamwork capacity, attitude, loyalty, and the motivation of people [53]. In the last millennium closing years, senior managers had to assume that "people, not cash, buildings or equipment, are the critical differentiators of a business enterprise" [54]. Wright, et al. [55], working from a knowledge resource-based view, argued that in specific situations competitive advantage can promote a "pool of human capital" which is larger than those groups, such as senior managers and other elites, who are traditionally identified as determining organizational success or failure. According to the RBV, human capital should be valuable, rare, inimitable, non-substitutable, and organized by firms to capture the value unleashed by these resources [56].

Taking into account the background of this research, the main objective of this study is to define and measure the human capital applied to eco-innovative processes by firms in the framework of RBV, so as to improve the knowledge about the human resources management available for eco-innovation. This objective implies enhancing the knowledge about the measurement of human capital, an area still under-studied in the eco-innovation literature, since it is not clear how the specific human capital applied to eco-innovative activities by businesses could be measured. Some authors argue that in the absence of market prices for human capital, the best procedure should be based on the firm's income statement data [57]. Against this argument, the specific human capital applied to eco-innovative processes including training, retention of the skills specificity, dedication, and experience are measured in this study applying the following conceptual model.

\subsection{Conceptual Model}

Human capital is increasingly recognized as a relevant driver of corporate competitiveness and sustainability [58]. The general display of human capital includes management ability to invest in this capital and defending the organization for its depletion. Thus, in order to measure the human capital applied to eco-innovative processes by firms, we define proxies of human capital investment that include number of workers, dedication, experience, training, and the actual presence of a leader in each specific department.

From the analysis of literature and the previous considerations, we define the following key research questions:

- (RQ1) How the specialized human resources available for eco-innovation can be measured?

- (RQ2) Is the specialized human capital a resource that influences the eco-innovative processes implemented by businesses?

These research questions imply identifying eco-innovative companies and trying to understand if variables related to human capital have any influence in their eco-innovative processes. To answer the first research question, human resources devoted to the eco-innovation within the firm are defined, classified, and measured from the RBV theoretical framework to assess the impact that these factors may have on business eco-innovation.

To this purpose, we define a human capital specific index (HCSI) based on different functional areas of the firms, such as the environmental management department, the energy and resources management department and the R \& D and innovation department (R \& D \& I). The outcome of the human capital effectiveness or valuation is the positive impact that these variables have in each eco-innovation-related functional area of firms (Figure 1). 


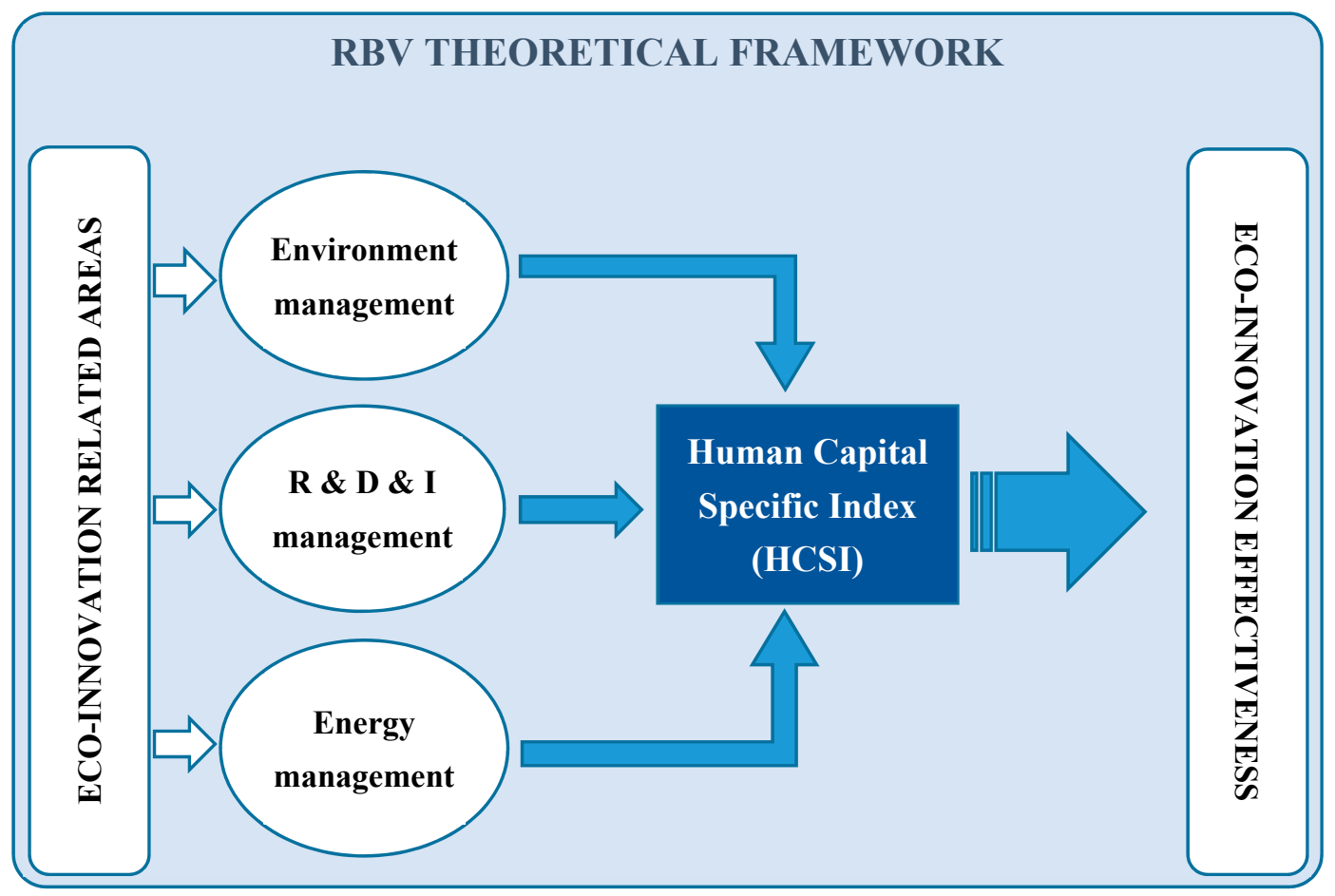

Figure 1. Description of the HCSI and business eco-innovation-related functional areas.

The research questions are answered by using the HCSI as a proxy, as described in the following section.

\section{Research Methods}

\subsection{Sample and Research Design}

To achieve the objectives of this study, a qualitative and quantitative study was carried out with a sample of companies counting on 50 or more employees, selected among proactive companies in the fields of eco-innovation, eco-design, and circular economy in Spain. The HCSI integrated index allowed us to explore some relationships in terms of human capital and the level of eco-innovation. In addition, the availability of human resources for eco-innovation was also measured $[15,42,44,50,59,60]$ considering the mentioned IC main functional areas of the firms that could be related to eco-innovative processes (the environment department, the R \& D \& I department, and the energy or resources management department), in line with Scarpellini, et al. [40].

The population from which to select a sample of eco-innovation interested companies was defined through a specific campaign promoting eco-innovation, eco-design, and circular economy in the Northeast Spanish regions of Aragon, Catalonia, Navarre, and the Basque Country, so as to count on companies with proven proactivity in the field of eco-innovation. Aiming at focusing the research on cases where eco-innovation can be considered as a truly competitive advantage, in line with the RBV theory, the sample was shortened to those companies operating in sectors with the greatest potential for eco-innovation. The companies operating in sectors related to the technologies referred to in the documents known as "BREFs" of the "Best Available Techniques" and, specifically, the industrial, transport and logistics, and waste sectors, were therefore selected and engaged in the research.

The nonpresence of a dedicated responsible person (whether partially or totally) for every one of the three areas studied was used as discarding criterion to avoid companies where a manager would be in charge of the studied areas as part of other, non-related to eco-innovation, departments, thus subject to biased decisions over the employees' training and dedication. 
A total number of 109 responses from the group of engaged companies was obtained, and the final number of valid complete observations for this study was 59. It should be highlighted that the main objective of this study required the collection of internal data from eco-innovation-interested companies, in order to assess the internal resources of businesses. Despite the limited size of the sample, the companies were fully identified by their value-added tax identification number (VAT code), allowing the collection of economic and financial data such as the turnover of companies, their size, and other relevant variables.

The empirical phase was performed by means of a survey aimed at company managers, designed with the objective of facilitating the segmentation of the composition and training of the workforce, the technology used, their main activity, the sub-sector in which they operate, the specialized staff training needs, etc. The survey was structured into two modules:

- General module: Identification and economic data of companies.

- Specific Module: Number of employees and characteristics, directly or indirectly devoted to the three intrinsic areas of eco-innovation: environmental management, energy/resources management, and R \& D \& I. The presence of a specific responsible person for each one of the three areas was already assumed as precondition.

Eco-innovation typically involves dynamic processes that strongly depend on the firm's business strategy. It needs a specific context where corporate entrepreneurship can flow, as well as specific human resources, trained, specialized and able to work in team. Subsequently, a construct was defined for each area of eco-innovation, including a set of human capital (HC)-related variables. The variables selected and analyzed for the study of companies' human resources and level of eco-innovation are detailed in Tables 1 and 2, respectively:

Table 1. Variables analyzed for the study of human resources (HR) available in the eco-innovation-related areas of firms.

\begin{tabular}{ccc}
\hline Variables & Type & Values \\
\hline Number of employees & continuous & Number \\
Dedication of responsible & dichotomous & Partial/Full \\
Age-Experience of responsible & continuous & Number \\
Training of responsible & dichotomous & Specific/No specific \\
Responsible degree & continuous & Text \\
\hline
\end{tabular}

Table 2. Description of the variable ECO-I level selected to measure the eco-innovative processes implemented by firms.

\begin{tabular}{lcc}
\hline Level of Eco-Innovation (ECO-I Level) & Type & Values \\
\hline $\begin{array}{l}\text { Percentage of total income invested in } \\
\text { environmental R \& D (own or acquired), }\end{array}$ & \\
$\begin{array}{l}\text { so as to get more eco-innovative products } \\
\text { and services }\end{array}$ & continuous & $\%$ \\
\hline
\end{tabular}

Aiming at avoiding bias related to the companies' size or sector, the main indicator to measure the eco-innovative processes implemented by firms within the current research was the companies' investment in environmental $\mathrm{R} \& \mathrm{D}$ for eco-innovation in relation to the companies' total income during the past three years (ECO-I level). Different authors have demonstrated that environmental R \& D investment or internal $R$ \& D activity facilitates eco-innovation in businesses $[4,15,61,62]$, and similar variables have been used in other studies to measure the level of resources applied to eco-innovative activities $[2,4,10]$. Therefore, the companies' ECO-I level was determined after the following ratio:

$$
\mathrm{ECO}-\mathrm{I} \text { Level }=\frac{\text { Investment in environmental R\&D for eco }- \text { innovation }}{\text { Total income }}
$$


The different results obtained after the ratio were subsequently categorized through a scale from 1 to 4, establishing four ranges of ECO-I level, as shown in Table 3 (none of the sample companies stated more than $10 \%$ investment in environmental $\mathrm{R} \& \mathrm{D}$ over their total income):

Table 3. ECO-I level categories.

\begin{tabular}{cc}
\hline R \& D Env. Investment/Total Income & ECO-I Level Category \\
\hline Less than $1 \%$ & $\mathbf{1}$ \\
From $1 \%$ to $2.9 \%$ & $\mathbf{2}$ \\
From $3 \%$ to $4.9 \%$ & $\mathbf{3}$ \\
From $5 \%$ to $10 \%$ & $\mathbf{4}$ \\
\hline
\end{tabular}

\subsection{Human Capital Specific Index (HCSI)}

As previously exposed, the HC dimension is undoubtedly crucial in the development of eco-innovation. The OECD [63] defined HC as "knowledge, skills, competencies and attributes embodied in individuals, which facilitate personal, social and economic well-being". HC has certain underlying characteristics, since it is embodied in humans [64]. HC is non-tradable and no market exists that would permit the exchange of $\mathrm{HC}$ assets; it has both qualitative and quantitative aspects; can be either general or specific; and contains external effects from the social environment and the institutional context in which they live, which continually shapes its acquisition $[64,65]$.

The HC practices that influence the relationship between the breadth of external knowledge and innovation [66] have been measured from a strategic perspective [67], and the R \& D team composition, focusing on size and degree of geographic dispersion across countries has been analyzed in the innovation literature [68]. In addition, human resources practices influence the employees' creativity to generate a sustainable competitive advantage for businesses [69]. However, the key skills and personal attributes relevant to HC have not been conceptualized in terms of communication, numeracy, and intra-personal skills (e.g., motivation/perseverance, learning to learn, self-discipline, problem solving, capacity to make judgements based on a relevant set of ethical values, and goals in life and inter-personal skills, e.g., teamwork or leadership).

Given the difficulty of assessing the level of qualification of the staff, the HCSI estimates the level of qualification allocated in the three eco-innovation-related areas by measuring the number of $\mathrm{PhD}$, masters, and post-graduate specialized staff and graduates. Besides, the HCSI will also measure the number of employees allocated in each functional area, their experience, and the level of dedication; as proxies of our proposal for internal HCSI inside the analyzed companies.

To build the construct the following steps were followed:

Firstly, a discrete analysis of the 59 responses was carried out for each variable in every area (environmental management (1), energy management (2) and R \& D \& I (3)), establishing the variables codes presented in Table 4. Secondly, in order to jointly analyze the responses, a construct was created for a human capital specificity index for each area, granting a total cumulative range for each area between 0 and 1, and a subsequent value to each of the four variables from 0 to 0.25 each, so as to apply a criterion of equivalence among variables.

Thirdly, correlation analyses between distributions were carried out, in order to assess if there is interrelation between the ECO-I level of the company and the human capital specificity indexes (one per area and another one as aggregated index), as shown in the model (Figure 2):
a. $\quad$ Eco-I level correlation with HC environmental management index (HCSI1_ENM).
b. Eco-I level correlation with HC energy management index (HCSI2_ERM).
c. Eco-I level correlation with HC R \& D \& I index (HCSI3_RDI).
d. Eco-I level correlation with the HC aggregated index for all areas (HCSI). 
Table 4. Research variables per area.

\begin{tabular}{|c|c|c|c|}
\hline \multirow[t]{2}{*}{ Variable/Area } & $\begin{array}{l}\text { Environmental } \\
\text { Management }\end{array}$ & Energy Mgment. & $R \& D \& I$ \\
\hline & From 0 to 1 & From 0 to 1 & From 0 to 1 \\
\hline Number of workers by area & EMPL1 (0-0.25) & EMPL2 (0-0.25) & EMPL3 (0-0.25) \\
\hline $\begin{array}{l}\text { Level of dedication of the person } \\
\text { responsible to the activity }\end{array}$ & DEDIC1 (0-0.25) & DEDIC2 (0-0.25) & DEDIC3 (0-0.25) \\
\hline $\begin{array}{l}\text { Working experience of the } \\
\text { responsible person }\end{array}$ & EXPER1 (0-0.25) & EXPER2 (0-0.25) & EXPER3 (0-0.25) \\
\hline $\begin{array}{l}\text { Specific training of the } \\
\text { responsible person }\end{array}$ & TRAIN1 (0-0.25) & TRAIN2 (0-0.25) & TRAIN3 (0-0.25) \\
\hline $\begin{array}{l}\text { HCSI } \\
(\max 3)\end{array}$ & $\begin{array}{l}\text { HCSI1_ENM } \\
(\max 1)\end{array}$ & $\begin{array}{l}\text { HCSI2_ERM } \\
(\max 1)\end{array}$ & $\begin{array}{l}\text { HCSI3_RDI } \\
(\max 1)\end{array}$ \\
\hline
\end{tabular}

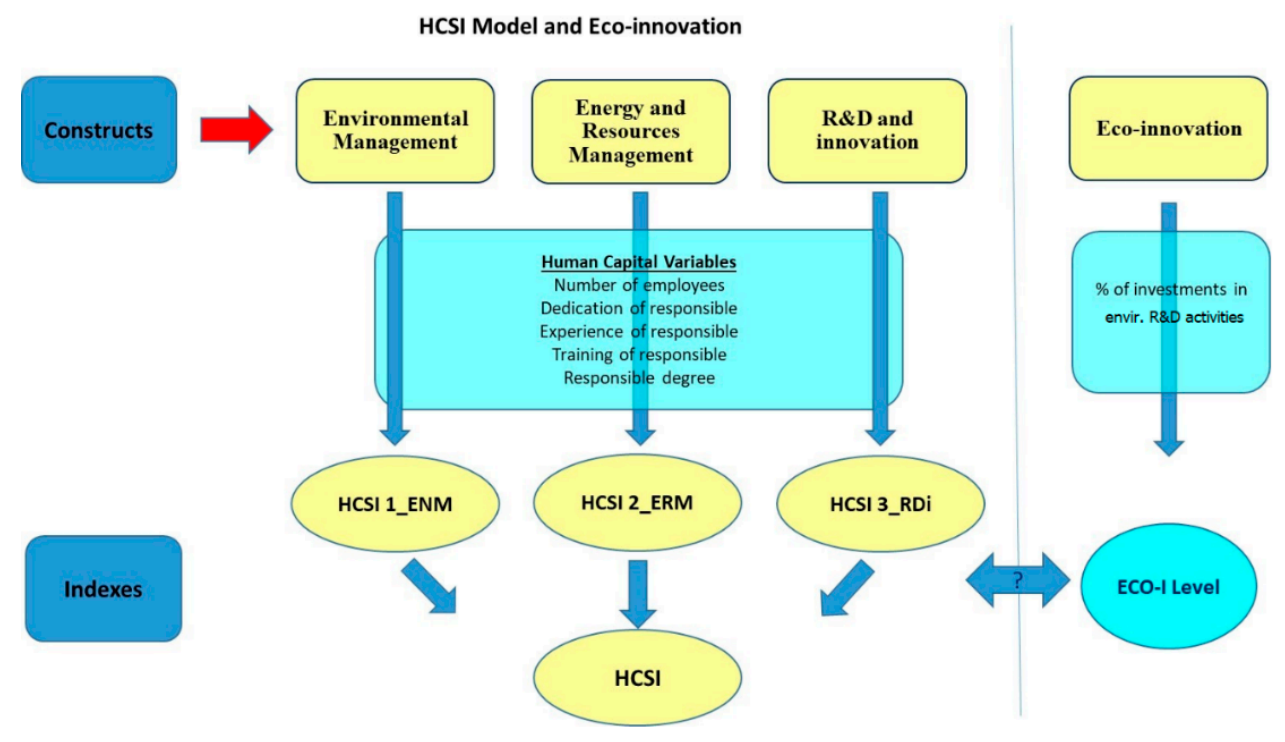

Figure 2. HCSI model. HCSI1_ENM: Eco-I level correlation with HC Environmental management index. HCSI2_ERM: Eco-I level correlation with HC energy management index. HCSI3_RDI: Eco-I level correlation with HC R \& D \& I index. HCSI: Eco-I level correlation with the HC aggregated index for all areas.

\section{Results \& Discussion}

\subsection{Main Results}

To determine the direction of the relationship between the obtained human capital scores and the ECO-I level, the correlation jointly analyses all four indexes (environment, energy management, R \& D $\& \mathrm{I}$, and the aggregate specificity index) as predictors of the Eco-I level, resulting in model 1 (Table 5). To that effect, a multiple linear regression was performed, with the ECO-I level as dependent variable, and the four HCSI indexes as independent variables. Results showed a significant correlation between the ECO-I level variable and the independent variables $(R=0.778)$.

Table 5. Statistical model summary.

\begin{tabular}{ccccccc}
\hline Model & R & R Square & $\begin{array}{c}\text { Adjusted R } \\
\text { Square }\end{array}$ & $\begin{array}{c}\text { Std. Error of } \\
\text { the Estimate }\end{array}$ & F & Sig. \\
\hline 1 & $0.778^{\text {a }}$ & 0.605 & 0.583 & 0.506 & 28.047 & 0.000 \\
\hline \multicolumn{7}{c}{${ }^{\text {a Predictors: (Constant), HCSI1_ENM, HCSI3_RDI, HCSI2_ERM. }}$. }
\end{tabular}


The final model can be synthetized by the following equation:

ECO-I Level = 2.619 HCSI1_ENM + 2.083 HCSI3_RDI + 0.972 HCSI2_ERM - 0.834

The model results are relevant since its Pearson R2 equals 0.605 , being significant enough for this type of sample. The HCSI2_ERM index, however, appears to be dependent on the remaining indexes, so it could be excluded from the model. Table 6 shows how the four indexes are positively correlated with the ECO-I level one on one:

Table 6. Indexes correlated with the HCSI.

\begin{tabular}{|c|c|c|c|c|c|c|}
\hline & & HCSI1_ENM & HCSI2_ERM & HCSI3_RDI & HCSI & ECO-I Level \\
\hline \multirow{2}{*}{ ECO-I } & Pearson Corr. & $0.657^{* *}$ & $0.574 * *$ & $0.599 * *$ & 0.770 ** & 1 \\
\hline & Sig. (2-tailed) & 0.000 & 0.000 & 0.000 & 0.000 & \\
\hline \multirow{2}{*}{ HCSI1_ENM } & Pearson Corr. & 1 & 0.706 ** & $0.335^{* *}$ & 0.825 ** & $0.657 * *$ \\
\hline & Sig. (2-tailed) & & 0.000 & 0.009 & 0.000 & 0.000 \\
\hline \multirow{2}{*}{ HCSI2_ERM } & Pearson Corr. & & 1 & 0.313 * & $0.818^{* *}$ & $0.574 * *$ \\
\hline & Sig. (2-tailed) & & & 0.016 & 0.000 & 0.000 \\
\hline \multirow{2}{*}{ HCSI3_RDI } & Pearson Corr. & & & 1 & $0.739 * *$ & $0.599 * *$ \\
\hline & Sig. (2-tailed) & & & & 0.000 & 0.000 \\
\hline \multirow{2}{*}{ HCSI } & Pearson Corr. & & & & 1 & $0.770 * *$ \\
\hline & Sig. (2-tailed) & & & & & 0.000 \\
\hline
\end{tabular}

** Correlation is significant at the 0.01 level (2-tailed). ${ }^{*}$ Correlation is significant at the 0.05 level (2-tailed).

The aggregated indicator is the one that better explains the ECO-I level, followed by the environmental area index (HCSI1_ENM). Given the potential risk of non-normality of the sample, nonparametric tests for independent samples (Kruskal-Wallis) were conducted, reaching the following results (Table 7):

Table 7. Kruskal-Wallis tests for human capital indexes.

\begin{tabular}{ccccc}
\hline & HCSI & HCSI1_ENM & HCSI2_ERM & HCSI3_RDI \\
\hline $\begin{array}{c}\text { Chi-Square } \\
\begin{array}{c}\text { Asymp. } \\
\text { significance }\end{array}\end{array}$ & 40.863 & 29.059 & 22.141 & 18.421 \\
\hline
\end{tabular}

Grouping Variable: ECO-I level.

The Kruskal-Wallis test applied to the human capital variables showed that, with a significance of 0.01 , the distribution of variables was not equivalent among the different groups of companies categorized after their ECO-I level. In addition, the sum of ranks confirmed the direct relationship existing between the different HC indexes and the ECO-I level, since higher ECO-I level implies higher degree of human capital, stating the positive correlation between the different specificity indexes and the ECO-I level (Table 8).

Table 8. Human capital indexes model.

\begin{tabular}{ccccccccc}
\hline & & HCSI & \multicolumn{2}{c}{ HCSI1_ENM } & \multicolumn{2}{c}{ HCSI2_ERM } & \multicolumn{2}{c}{ HCSI3_RDI } \\
\hline ECO-I & N & Mean Rank & N & Mean Rank & N & Mean Rank & N & Mean Rank \\
1 & 8 & 9.88 & 8 & 9.56 & 8 & 20.19 & 8 & 12.38 \\
2 & 31 & 22.97 & 31 & 25.74 & 31 & 23.29 & 31 & 27.79 \\
3 & 16 & 48.25 & 16 & 45.53 & 16 & 44.06 & 16 & 37.91 \\
4 & 4 & 51.75 & 4 & 41.75 & 4 & 45.38 & 4 & 50.75 \\
& 59 & & 59 & & 59 & & 59 & \\
\hline
\end{tabular}


The specific analysis of the weight over the ECO-I level attributable to every variable, showed that within the areas of environment and energy management, the level of dedication to the activity and the number of workers in the activity were the most relevant variables. In the specific area of environment management, although significant, the specific training did not present a high correlation and the working experience appeared to be not correlated. Similar outcomes were found in the area of energy management, with working experience and specific training not being correlated variables (Tables 9 and 10).

Table 9. Results for environmental management human capital.

\begin{tabular}{llccccc}
\hline \multicolumn{2}{c}{ Environment Manag. Area } & EMPL1.ENV & DEDIC1.ENV & EXPER1.ENV & TRAIN1.ENV & ECO-I Level \\
\hline \multirow{2}{*}{ EMPL1.ENV } & Pearson Correlation & 1 & -0.080 & -0.103 & 0.206 & $\mathbf{0 . 3 6 5}$ \\
& Sig. (2-tailed) & & 0.545 & 0.436 & 0.118 & 0.004 \\
DEDIC1.ENVV & Pearson Correlation & & 1 & -0.173 & 0.064 & $\mathbf{0 . 4 2 0}$ \\
& Sig. (2-tailed) & & & 0.189 & 0.632 & 0.001 \\
EXPER1.ENVV & Pearson Correlation & & & 1 & -0.059 & 0.201 \\
& Sig. (2-tailed) & & & 0.657 & 0.127 \\
TRAIN1.ENV & Pearson Correlation & & & & 1 & $\mathbf{0 . 2 7 4}$ \\
& Sig. (2-tailed) & & & 0.035 \\
\hline
\end{tabular}

Table 10. Results for energy management human capital.

\begin{tabular}{llccccc}
\hline \multicolumn{2}{c}{ Energy Manag. Area } & EMPL2.ENR & DEDIC2.ENR & EXPER2.ENR & TRAIN2.ENR & ECO-I Level \\
\hline \multirow{2}{*}{ EMPL2.ENR } & Pearson Correlation & 1 & -0.114 & 0.022 & -0.112 & $\mathbf{0 . 3 6 5}$ \\
& Sig. (2-tailed) & & 0.388 & 0.867 & 0.397 & 0.004 \\
DEDIC2.ENR & Pearson Correlation & & 1 & -0.091 & 0.071 & $\mathbf{0 . 3 9 3}$ \\
& Sig. (2-tailed) & & & 0.495 & 0.591 & 0.002 \\
EXPER2.ENR & Pearson Correlation & & & 1 & -0.206 & 0.177 \\
& Sig. (2-tailed) & & & & 0.117 & 0.180 \\
TRAIN2.ENR & Pearson Correlation & & & & 1 & 0.111 \\
& Sig. (2-tailed) & & & & 0.405 \\
\hline
\end{tabular}

${ }^{* *}$ Correlation is significant at the 0.01 level (2-tailed).

Regarding the R \& D \& I area, the four variables were positively correlated to the ECO-I level, although the most relevant ones were the specific training and the level of dedication to the activity, and the least, the number of employees in the activity (Table 11).

Table 11. Results for R \& D \& I human capital.

\begin{tabular}{|c|c|c|c|c|c|c|}
\hline \multicolumn{2}{|c|}{ R \& D \& I Area } & \multirow{2}{*}{$\begin{array}{c}\text { EMPL3.IDI } \\
1\end{array}$} & \multirow{3}{*}{$\begin{array}{c}\text { DEDIC3.IDI } \\
-0.366^{* *} \\
0.004\end{array}$} & \multirow{3}{*}{$\begin{array}{c}\text { EXPER3.IDI } \\
-0.139 \\
0.295\end{array}$} & \multirow{3}{*}{$\begin{array}{c}\text { TRAIN3.IDI } \\
-0.003 \\
0.983\end{array}$} & \multirow{2}{*}{$\begin{array}{c}\text { ECO-I level } \\
0.288^{*}\end{array}$} \\
\hline & Pearson Correlation & & & & & \\
\hline EMPL3.IDI & Sig. (2-tailed) & & & & & 0.027 \\
\hline \multirow{2}{*}{ DEDIC3.IDI } & Pearson Correlation & & 1 & $0.281 *$ & $0.291 *$ & $0.332 *$ \\
\hline & Sig. (2-tailed) & & & 0.031 & 0.025 & 0.010 \\
\hline \multirow{2}{*}{ EXPER3.IDI } & Pearson Correlation & & & 1 & 0.229 & 0.318 * \\
\hline & Sig. (2-tailed) & & & & 0.081 & 0.014 \\
\hline \multirow{2}{*}{ TRAIN3.IDI } & Pearson Correlation & & & & 1 & $0.375^{* *}$ \\
\hline & Sig. (2-tailed) & & & & & 0.003 \\
\hline \multirow{2}{*}{ ECO-I } & Pearson Correlation & & & & & 1 \\
\hline & Sig. (2-tailed) & & & & & \\
\hline
\end{tabular}

${ }^{* *}$ Correlation is significant at the 0.01 level (2-tailed). ${ }^{*}$ Correlation is significant at the 0.05 level (2-tailed).

The different activities undertaken by companies may have an effect on the skills and management of the human capital, since some innovative activities may require specific conditions for this capital. In order to assess this potential proxy linked to the companies' activities, a sectoral analysis was also 
performed, defining five main categories or sectors after the higher or lower degree of transformation and use of energy implied by the activities involved. The categorization of companies according to the main sector in which they operate is presented below:

- $\quad$ Energy intensive industry

- Logistics and transport

- Industrial manufacture of goods

- Consumption goods manufacture

- $\quad$ Services

Both the Kruskal-Wallis tests and the cluster analysis showed no significant behavioral differences among companies after the sectors to which they belong. The multidimensional scaling-dispersion analysis performed (MDS) also failed to bring any significant relationship between the sector and the score in all four constructs and the ECO-I level, as shown in the graph below, where companies positions after their scores are not clearly related to the constructs vectors (Figure 3):

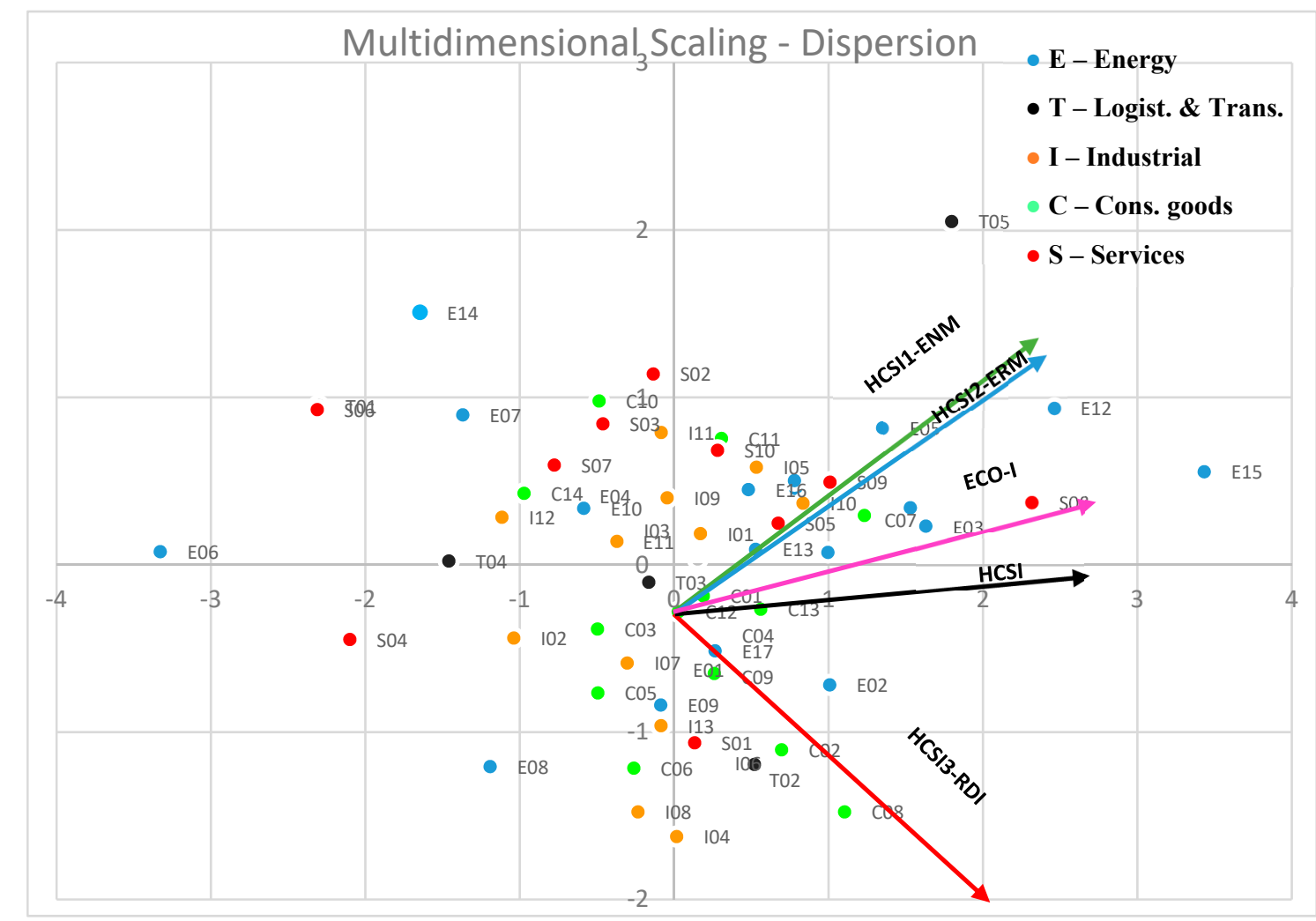

Figure 3. Multidimensional analysis.

The graph presents the companies dispersion through a multidimensional scaling of the HCSI variables in two dimensions, where the vectors show the direction of the variable defining them. The five colors of the spots represent the five different sectors analyzed. The model does not show a clear pattern of companies after their sector or size (measured by turnover or number of employees), although it can be observed that companies belonging to the 'consumption goods manufacture' sector are located around the positive sense of the HCSI_RDI. As a general trend, the vectors for HCSI and ECO-I level, and the vectors for Environment Management and Energy Management follow a similar pattern, respectively, especially among 'energy intensive' sector companies, while the vector for HCSI_RDI presents a different behavior. 


\subsection{Discussion}

Some practitioners and scholars have argued a positive relationship between human capital and business eco-innovation, since investment in this specific capital would contribute to improving company eco-innovative processes. The results of this research are remarkably congruent with those obtained in previous literature that links human capital with organizational performance. That is, the better an organization performs in managing its human capital, the better the level of correlation is between the ECO-I level and the HCSI index.

The outcomes derived from the results obtained through the series of statistical tests and analyses performed can be summarized as follows:

- The specificity of human resources, in aggregated form, is decisive for the level of eco-innovation of the company, and correlates positively, that is, to greater specificity of human resources, higher ECO-I level.

- The specificity in each of the three areas (ENV, ENR, and R \& D \& I), is also linked to the ECO-I level of the company, although not so obviously in the area of energy management (ENR).

- The most relevant variable of the index in terms of its correlation with the ECO-I level is the level of dedication to the activity, followed by the number of workers in the activity and the specific training. The working experience is only observed as important in the case of R \& D \& I.

- The MDS analysis per activity sector is not conclusive, although the results suggest a similar behavior for environmental management and energy management vectors, and for HCSI and ECO-I level vectors. The latter two vectors would actually be rather similar to the first ones, would the R \& D \& I differentiated trend be discarded.

The research has proven that specialization of human resources is positively related to the eco-innovation in the company. The more specialized HC is in terms of dedication, experience, and skills, the higher the company scores in the variable ECO-I level. Therefore, influence of specialized human resources is relevant to the eco-innovative activities in business.

The specific index developed throughout the research proves that the existence of specialized human capital is linked to the ECO-I level. The number of dedicated employees in every area (environment management, energy management, and R \& D \& I) positively influences the eco-innovation activity of the company. Consequently, the human capital can be considered as a specific resource that influences the level of eco-innovation implemented by business.

\section{Conclusions}

The resources that are considered as determinant factors for eco-innovation have generally been analyzed, whether in the business strategy literature, or as drivers for the decision-making process. However, the specialized human capital, as a relevant resource for the eco-innovative processes in businesses, is still under study. Thus, this research attempts to define and measure human capital through a set of indicators developed within the intellectual capital framework. The achieved results contribute to the knowledge about resources specifically applied to the eco-innovative businesses that are seldom considered in the literature due to the complexity of obtaining data of internal eco-innovative processes.

The positive relationship derived from the research between human capital skills, capabilities, and management available in firms and their level of eco-innovation strengthens the case of eco-innovation as a phenomenon which can be understood from the RBV theoretical framework.

The selection of variables to measure the human resources most directly related to the eco-innovation in a firm represents one of the contributions of this work, since they are not differentiated in such a way in the vast majority of previous studies on the subject. The system of indicators developed in this study can be applied to the human capital management with the objective of allowing for a clear picture of the strategic resources applied to eco-innovation. Moreover, it can be easily adapted to a given type of firm and, therefore, serve to compare companies belonging to the same sector of activity. 
In addition, another relevant outcome of this research is the analysis of the interrelation among the human capital available in different functional areas related to the eco-innovative activities of firms and their investment in eco-innovation. This relation is presenting not only the interrelation between those areas but also the eco-innovative processes implemented by firms, since this contribution can be applied by practitioners in eco-innovative firms that might be positively biased towards the three areas or even consider them all as part of a general approach towards sustainability, paving the way to other potential interrelations such as those with circular economy (from the resources side), or with corporate social responsibility (from the stakeholders' perspective). This approach could also constitute the basis to further lines of research and could help to supplement the main limitation of this study, linked to the size of the sample and its regional characteristics.

We believe there is room for extensive debate to consider knowledge through the human capital and relational and structural capital (intellectual capital) as a main key asset to explain the company eco-innovation effectiveness, developing both conceptual and quantitative measuring processes, so as to include the constructs indicators into the future research.

Author Contributions: All the authors contributed substantially and equally to the work reported in this paper.

Funding: This research was made possible owing to funding from the Spanish Ministry of Economy, Industry and Competitiveness, project "Conta-Circular" ECO2016-74920-C2-1-R.

Acknowledgments: This study was partially co-financed by the Regional Government of Aragón in the framework of the Research Group Ref.: S33_17R. The authors are particularly grateful for the contribution of the companies that participated in the project ECO2013-45599-R and that provided the necessary data for this research. The contribution of Alfonso Aranda-Usón is also acknowledged.

Conflicts of Interest: The authors declare no conflict of interest.

\section{References}

1. Scarpellini, S.; Aranda, A.; Aranda, J.; Llera, E.; Marco, M. R\&D and eco-innovation: Opportunities for closer collaboration between universities and companies through technology centers. Clean Technol. Environ. Policy 2012, 14, 1047-1058. [CrossRef]

2. Portillo-Tarragona, P.; Scarpellini, S.; Moneva, J.; Valero-Gil, J.; Aranda-Usón, A. Classification and measurement of the firms' resources and capabilities applied to eco-innovation projects from a resource-based view perspective. Sustainability 2018, 10, 3161. [CrossRef]

3. Bocken, N.M.P.; Farracho, M.; Bosworth, R.; Kemp, R. The front-end of eco-innovation for eco-innovative small and medium sized companies. J. Eng. Technol. Manag. 2014, 31, 43-57. [CrossRef]

4. Lee, K.-H.H.; Min, B. Green R\&D for eco-innovation and its impact on carbon emissions and firm performance. J. Clean. Prod. 2015, 108, 534-542. [CrossRef]

5. Díaz-García, C.; González-Moreno, Á.; Sáez-Martínez, F.J. Eco-innovation: Insights from a literature review. Innovation 2015, 17, 6-23. [CrossRef]

6. Kraaijenbrink, J.; Spender, J.-C.; Groen, A.J. The RBV: A review and assessment of its critiques. J. Manag. 2010, 36, 349-372. [CrossRef]

7. Song, M.; Di Benedetto, C.A.; Nason, R.W. Capabilities and financial performance: The moderating effect of strategic type. J. Acad. Mark. Sci. 2007, 35, 18-34. [CrossRef]

8. Barney, J.B. Firm resources and sustained competitive advantage. J. Manag. 1991, 17, 99-120. [CrossRef]

9. Barney, J.B. Is the resource-based "view" a useful perspective for strategic management research? Yes. Acad. Manag. Rev. 2001, 26, 41-56. [CrossRef]

10. Ketata, I.; Sofka, W.; Grimpe, C. The role of internal capabilities and firms' environment for sustainable innovation: Evidence for Germany. $R$ D Manag. 2015, 45, 60-75. [CrossRef]

11. Horbach, J.; Rammer, C.; Rennings, K. Determinants of eco-innovations by type of environmental impact-The role of regulatory push/pull, technology push and market pull. Ecol. Econ. 2012, 78, 112-122. [CrossRef]

12. Andersen, M.M. Entrepreneurship and innovation-Organizations, institutions, eco-innovation-Towards a taxonomy and a theory. In Proceedings of the DRUID 25th Conference 2008 on Entrepreneurship and Innovation, Frederiksberg, Denmark, 17-20 June 2008; DIME Accademy, Ed.; DIME Accademy: Aalborg, Denmark, 2008; pp. 1-16. 
13. Blum-Kusterer, M.; Hussain, S.S. Innovation and corporate sustainability: An investigation into the process of change in the pharmaceuticals industry. Bus. Strategy Environ. 2001, 10, 300-316. [CrossRef]

14. Horbach, J. Determinants of environmental innovation-New evidence from German panel data sources. Res. Policy 2008, 37, 163-173. [CrossRef]

15. Cruz-Cázares, C.; Bayona-Sáez, C.; García-Marco, T. You can't manage right what you can't measure well: Technological innovation efficiency. Res. Policy 2013, 42, 1239-1250. [CrossRef]

16. Cainelli, G.; Mazzanti, M.; Zoboli, R. Environmental innovations, complementarity and local/global cooperation: Evidence from North-East Italian industry. Int. J. Technol. Policy Manag. 2011, 11, 328-368. [CrossRef]

17. Cuerva, M.C.; Triguero-Cano, Á.; Córcoles, D. Drivers of green and non-green innovation: Empirical evidence in Low-Tech SMEs. J. Clean. Prod. 2014, 68, 104-113. [CrossRef]

18. Petruzzelli, A.M.; Dangelico, R.M.; Rotolo, D.; Albino, V. Organizational factors and technological features in the development of green innovations: Evidence from patent analysis. Innov. Manag. Policy Pract. 2011, 13, 291-310. [CrossRef]

19. Chang, C.; Chen, Y. Green organizational identity and green innovation. Manag. Decis. 2013, 51, $1056-1070$. [CrossRef]

20. Del Río, P.; Carrillo-Hermosilla, J.; Könnölä, T.; Bleda, M. Resources, capabilities and competences for eco-innovation. Technol. Econ. Dev. Econ. 2016, 22, 274-292. [CrossRef]

21. Bartlett, D.; Trifilova, A. Green technology and eco-innovation: Seven case-studies from a Russian manufacturing context. J. Manuf. Technol. Manag. 2010, 21, 910-929. [CrossRef]

22. Cameron, K. Responsible leadership as virtuous leadership. J. Bus. Ethics 2011, 98, 25-35. [CrossRef]

23. Groves, K.S.; LaRocca, M.A. An empirical study of leader ethical values, transformational and transactional leadership, and follower attitudes toward corporate social responsibility. J. Bus. Ethics 2011, 103, 511-528. [CrossRef]

24. Pless, N.M. Understanding responsible leadership: Role identity and motivational drivers. J. Bus. Ethics 2007, 74, 437-456. [CrossRef]

25. Pless, N.; Maak, T. Responsible leadership: Pathways to the future. J. Bus. Ethics 2011, 98, 3-13. [CrossRef]

26. Hall, B.H. Investment and Research and Development at the Firm Level: Does the Source of Financing Matter? National Bureau of Economic Research Working Paper; National Bureau of Economic Research: Cambridge, MA, USA, 1992.

27. Barney, J.; Wright, P. On becoming a strategic partner: The role of human resources in gaining competitive advantage. Hum. Resour. Manag. 1998, 37, 31-46. [CrossRef]

28. Coff, R.W. Human assets and management dilemmas: Coping with hazards on the road to resource-based theory. Acad. Manag. Rev. 1997, 22, 374-402. [CrossRef]

29. Hatch, N.W.; Dyer, J.H. Human capital and learning as a source of sustainable competitive advantage. Strateg. Manag. J. 2004, 25, 1155-1178. [CrossRef]

30. Hitt, M.A.; Bierman, L.; Shimizu, K.; Kochhar, R. Direct and moderating effects of human capital on strategy and performance in professional service firms: A resource-based perspective. Acad. Manag. J. 2001, 44, 13-28. [CrossRef]

31. Kor, Y.Y.; Leblebici, H. How do interdependences among human-capital deployment, development, and diversification strategies affect firms' financial performance? Strateg. Manag. J. 2005, 26, 967-985. [CrossRef]

32. Skaggs, B.C.; Youndt, M.A. Strategic positioning, human capital, and performance in service organizations: A customer interaction approach. Strateg. Manag. J. 2004, 25, 85-99. [CrossRef]

33. Kemp, R.; Soete, L. The greening of technological progress. An evolutionary perspective. Futures 1992, 24, 437-457. [CrossRef]

34. Pereira, Á.; Vence, X. Key business factors for eco-innovation: An overview of recent firm-level empirical studies. Cuad. Gest. 2012, 12, 73-103. [CrossRef]

35. Georg, S.; Røpke, I.; Jørgensen, U. Clean technology-Innovation and environmental regulation. Environ. Resour. Econ. 1992, 2, 533-550.

36. Winn, S.F.; Roome, N.J. R\&D management responses to the environment: Current theory and implications to practice and research. $R$ D Manag. 1993, 23, 147-160. [CrossRef]

37. Lall, S. Technological capabilities and industrialization. World Dev. 1992, 20, 165-186. [CrossRef] 
38. Curado, C.; Henriques, L.; Bontis, N. Intellectual capital disclosure payback. Manag. Decis. 2011, 49, 1080-1098. [CrossRef]

39. Chen, C.-J.; Huang, J.-W. Strategic human resource practices and innovation performance-The mediating role of knowledge management capacity. J. Bus. Res. 2009, 62, 104-114. [CrossRef]

40. Scarpellini, S.; Ortega-Lapiedra, R.; Marco-Fondevila, M.; Aranda-Usón, A. Human capital in the eco-innovative firms: A case study of eco-innovation projects. Int. J. Entrep. Behav. Res. 2017, 23, 919-933. [CrossRef]

41. Scarpellini, S.; Marín-Vinuesa, L.M.; Portillo-Tarragona, P.; Moneva, J.M. Defining and measuring different dimensions of financial resources for business eco-innovation and the influence of the firms' capabilities. J. Clean. Prod. 2018, 204, 258-269. [CrossRef]

42. Halila, F.; Rundquist, J. The development and market success of eco-innovations: A comparative study of eco-innovations and "other" innovations in Sweden. Eur. J. Innov. Manag. 2011, 14, 278-302. [CrossRef]

43. Kijek, T.; Kasztelan, A. Eco-innovation as a factor of sustainable development. Problenmy Ekorozw. 2013, 8, 103-111.

44. Paraschiv, D.M.; Nemoianu, E.L.; Langa, C.A.; Szabó, T. Eco-innovation, responsible leadership and organizational change for corporate sustainability. Amfiteatru Econ. 2012, 14, 404-419.

45. Kemp, R.; Pearson, P.; Arundel, A.; Borup, M.; Dorronsoro, I.C.; Andersen, D.; De Vries, F.; Lázaro, J.E.; Foxon, T.; Sedano, J.A.G.; et al. Final report MEI project about measuring eco-innovation. UM Merit Maastricht 2007, 32, 1-120.

46. González-Benito, J.; González-Benito, Ó. A review of determinant factors of environmental proactivity. Bus. Strateg. Environ. 2006, 15, 87-102. [CrossRef]

47. Aragón-Correa, J.A.; Rubio-López, E. Proactive corporate environmental strategies: Myths and misunderstandings. Long Range Plan. 2007, 40, 357-381. [CrossRef]

48. Sharma, P.; Sharma, S. Drivers of proactive environmental strategy in family firms. Bus. Ethics Q. 2011, 21, 309-334. [CrossRef]

49. Antonioli, D.; Mancinelli, S.; Mazzanti, M. Is environmental innovation embedded within high-performance organisational changes? The role of human resource management and complementarity in green business strategies. Res. Policy 2013, 42, 975-988. [CrossRef]

50. Arundel, A. Measuring eco-innovation. Account. Financ. 1980, 20, 146. [CrossRef]

51. Edvinsson, L.; Malone, M.S. Intellectual Capital: Realizing Your Company's True Value by Finding Its Hidden Brainpower; Harper Business: New York, NY, USA, 1997.

52. Cater, T.; Cater, B. (In)tangible resources as antecedents of a company's competitive advantage and performance. J. East Eur. Manag. Stud. 2009, 14, 186-209. [CrossRef]

53. Sydler, R.; Haefliger, S.; Pruksa, R. Measuring intellectual capital with financial figures: Can we predict firm profitability? Eur. Manag. J. 2014, 32, 244-259. [CrossRef]

54. Fitz-Enz, J. The ROI of Human Capital: Measuring the Economic Value of Employee Performance; AMACOM: Saranac Lake, NY, USA, 2000; ISBN 0814413323.

55. Wright, P.M.; McMahan, G.C.; McWilliams, A. Human resources and sustained competitive advantage: A resource-based perspective. Int. J. Hum. Resour. Manag. 1994, 5, 301-326. [CrossRef]

56. Battagello, F.M.; Cricelli, L.; Grimaldi, M. Prioritization of strategic intangible assets in make/buy decisions. Sustainability 2019, 11, 1267. [CrossRef]

57. Wyatt, A.; Frick, H. Accounting for investments in human capital: A review. Aust. Account. Rev. 2010, 20, 199-220. [CrossRef]

58. Xu, J.; Wang, B. Intellectual capital, financial performance and companies' sustainable growth: Evidence from the Korean manufacturing industry. Sustainability 2018, 10, 4651. [CrossRef]

59. Doran, J.; Ryan, G. Regulation and firm perception, eco-innovation and firm performance. Eur. J. Innov. Manag. 2012, 15, 421-441. [CrossRef]

60. Triguero, A.; Moreno-Mondéjar, L.; Davia, M.A. The influence of energy prices on adoption of clean technologies and recycling: Evidence from European SMEs. Energy Econ. 2014, 46, 246-257. [CrossRef]

61. Parthasarthy, R.; Hammond, J. Product innovation input and outcome: Moderating effects of the innovation process. J. Eng. Technol. Manag. 2002, 19, 75-91. [CrossRef]

62. Triguero, A.; Moreno-Mondéjar, L.; Davia, M.A. Leaders and laggards in environmental innovation: An empirical analysis of SMEs in Europe. Bus. Strateg. Environ. 2016, 25, 28-39. [CrossRef] 
63. Organisation for Economic Co-Operation and Development. The Well-Being of Nations_The Role of Human and Social Capital; Organisation for Economic Co-Operation and Development: Paris, France, 2001; pp. 1-121.

64. Natoli, R. Indicators of Economic and Social Progress: An Assessment and an Alternative. Ph.D. Thesis, Victoria University, Melbourne, Australia, 2008.

65. Laroche, M.; Merette, M.; Ruggeri, G.C. On the concept and dimensions of human capital in a knowledge-based economy context. Can. Public Policy 1999, 25, 87-100. [CrossRef]

66. Ardito, L.; Petruzzelli, A.M. Breadth of external knowledge sourcing and product innovation: The moderating role of strategic human resource practices. Eur. Manag. J. 2017, 35, 261-272. [CrossRef]

67. Beugelsdijk, S. Strategic human resource practices and product innovation. Organ. Stud. 2008, 29, 821-847. [CrossRef]

68. Ardito, L.; Petruzzelli, A.M.; Albino, V. Investigating the antecedents of general purpose technologies: A patent perspective in the green energy field. J. Eng. Technol. Manag. 2016, 39, 81-100. [CrossRef]

69. Lee, J.; Kim, S.; Lee, J.; Moon, S. Enhancing employee creativity for a sustainable competitive advantage through perceived human resource management practices and trust in management. Sustainability 2019, 11, 2305. [CrossRef]

(C) 2019 by the authors. Licensee MDPI, Basel, Switzerland. This article is an open access article distributed under the terms and conditions of the Creative Commons Attribution (CC BY) license (http://creativecommons.org/licenses/by/4.0/). 